\title{
ПЕДАГОГІЧНА ПАРЕМІЯ В СУЧАСНИХ УКРАЇНСЬКІЙ, НІМЕЦЬКІЙ І РОСІЙСЬКІЙ МОВАХ: ЛІНГВОКУЛЬТУРОЛОГІЧНИЙ АСПЕКТ
}

\author{
ГАЛИНА ПАЛИЦЯ \\ Дрогобицький державний педагогічний університет імені Івана Франка, \\ Дрогобич - Україна \\ PAREMIA PEDAGOGICZNA WE WSPÓŁCZESNYM JĘZYKU UKRAIŃSKIM, \\ NIEMIECKIM I ROSYJSKIM: ASPEKT LINGWOKULTUROLOGICZNY

\section{HAEYNA PALYCIA} \\ Państwowy Uniwersytet Pedagogiczny imienia Iwana Franki w Drohobyczu, \\ Drohobycz — Ukraina \\ STRESZCZENIE. W niniejszym artykule przedmiot analizy stanowi paremia pedago- \\ giczna, ze względu na osobliwości jej prezentacji w ukraińskiej, rosyjskiej i niemieckiej \\ wspólnotach lingwokulturowych. Określona została również specyfika językowej egzem- \\ plifikacji głównych pojęć w odniesieniu do konceptosfery „Uczenie się” i „Wychowanie” \\ w odpowiednich systemach językowych.
}

\section{PEDAGOGICAL PAREMIA IN MODERN UKRAINIAN, GERMAN AND RUSSIAN: CULTURAL-LINGUISTIC ASPECT}

\section{HALYNA PALYTSYA}

Drohobych State Ivan Franko Pedagogical University, Drohobych — Ukraine

ABSRACT. The article focuses on the analysis of pedagogical paremia, its peculiarities of presentation in Ukrainian, Russian and German. The peculiarities of linguistic expression of notions and concept spheres „Teaching” and „Education” have been highlighted in the compared languages.

\begin{abstract}
$\mathrm{C}$
ьогодні в лінгвістиці опрацьовано низку підходів до опису мовних явищ, серед яких антропоцентризм і дискурсоцентризм є, з одного боку, пріоритетними, а 3 іншого, - базовими для нових лінгвістичних дисциплін. Однією з таких маргінальних галузей є лінгвокультурологія, виникнення якої зумовлене новою науковою парадигмою, що поставила в центр мовну особистість, мовленнєву компетенцію якої визначає суспільство, культура, епоха, i, зрештою, - конкретні умови життя. Отже, обгрунтованими на сьогодні є лінгвокультурологічні дослідження, в основі яких — ідея презентації явищ мови з урахуванням культури народу, зокрема ії носія, що розкриває особливості його менталітету, свідомості, стереотипи мислення тощо.

„Стереотипи належать свідомості, а в мовленні вони виявляються у вигляді словесних штампів, кліше, зокрема фразеологізмів, прислів'їв, приказок”, демонструючи національну своєрідність вербальної та невербальної комуні-
\end{abstract}

${ }^{1}$ Т. Ф. Осіпова, Параметри вербальної і невербальної комунікаиії в пареміях, дис. канд. філол. наук, Харків 2010, с. 8. 
кації. Це дає підстави зараховувати паремії до етнопсихологічно детермінованих засобів мови, оскільки їх семантика базується на національно-культурних ознаках матеріальної культури та свідомості ${ }^{2}$. Саме тому окреслену сферу мови в останні роки все інтенсивніше досліджують саме в лінгвокультурологічному ракурсі, доповнюючи цінною інформацією уявлення про особливості різних лінгвокультур.

Паремії, як відомо, становлять цікавий для лінгвокультурологічних досліджень пласт. Різні аспекти вивчення паремій репрезентовані в працях таких сучасних учених, як Л. Авксентьєв, І. Голубовська, К. Глуховцева, В. Мокієнко, В. Ужченко, В. Чабаненко, Т. Осіпова та ін. Пареміологічна сфера на позначення педагогічних ситуацій у науковій лінгвістичній літературі до сьогодні ще не висвітлена, як не була предметом розгляду й характеристика особливостей iï презентації в різних лінгвокультурах, що й спонукало обрати саме цей аспект предметом дослідження.

Дослідницький матеріал становлять паремії сучасних української, російської та німецької мов на позначення ситуацій, що виникають у сфері педагогічної комунікації, які пропонуємо номінувати „педагогічні паремії”.

Джерельною базою цієї наукової розвідки стали такі словники паремій, як Німецько-украӥнський фразеологічний словник (усталені порівняння) ${ }^{3}$; Перлини народної мудростін; Русские народные загадки, пословиць, поговорки Русские пословиць и поговорки ; Украӥнські приказки, прислів'я і таке інше Українські прислів'я та приказки ; Duden. Redewendungen und sprichwörtliche Redensarten. Wörterbuch der deutschen Idiomatik ${ }^{9}$.

Об'єктом дослідження слугують педагогічні паремії сучасних української, російської та німецької мов. Предметом - лінгвокультурологічна специфіка пареміологічної сфери на позначення ситуацій, що виникають у сфері педагогічної комунікації в українській, російській і німецькій лінгвокультурах.

Мета дослідження - виявлення специфіки педагогічних паремій в українській, російській і німецькій лінгвокультурах.

Паремії, як відомо, є засобом збереження і трансформації людського досвіду, культури народу, його традицій і звичаїв, чим вони імплікують кумулятивну та директивну функції ${ }^{10}$. Фіксуючи духовний і матеріальний досвід людства, вони містять ,і моральний закон, і здоровий глузд, виражені в короткому висловлюванні, що заповідали предки як керівництво потомкам"11. Зазначене пояснює той факт, що саме названі одиниці мають широке застосування в ситуаціях, що виникають у сфері педагогічної комунікації.

Педагогічна паремія - поняття, що на даний час ще належно не окреслене в мовознавчій літературі, що й спонукає зупинитися на ньому більш

${ }^{2}$ Г. Ю. Богдан ович, Русский язык в аспекте проблем лингвокультурологии, Симферополь 2002, c. 121.

${ }^{3}$ К. І. Мізін, Німецько-украӥнський фразеологічний словник (усталені порівняння), Вінниця 2005.

${ }^{4}$ О. Ф. Кудіна, О. П. Пророченко, Перлини народної мудрості, Вінниця 2005.

${ }^{5}$ Русские народные загадки, пословищы, поговорки, сост. Ю. Г. Круглов, Москва 1990.

${ }^{6}$ Русские пословицы и поговорки, под ред. В. П. Аникина, Москва 1988.

${ }^{7}$ Українські приказки, прислів'я і таке інше, уклав М. Номис, Київ 1993.

8 Украӥнські прислів'я та приказки, упор. та передм. В. Бойка, Київ 1978.

${ }^{9}$ Duden. Redewendungen und sprichwörtliche Redensarten. Wörterbuch der deutschen Idiomatik, Bearb. von G. Drosdowski und W. Scholze-Stubenrecht, Mannheim; Leipzig; Wien; Zürich, Dudenverlag, 1998, в. 11.

${ }^{10}$ Т. Ф. Осіпова, Зазнач. праия.

${ }^{11}$ Ф. И. Буслаев, История граматики русского языка, Москва 1959, с. 204. 
докладно. Під терміном „педагогічна паремія” розуміємо сталу синтаксичну одиницю, що вживається у сфері педагогічної комунікації, позначаючи розмаїття аспектів педагогічної дійсності, найважливішими з яких є: 1) навчальний процес; 2) виховний процес; 3) учасники навчально-виховного процесу (вчитель / вихователь, учень / вихованець). Важливо зазначити, що, вживаючи термін „навчально-виховний процес”, розуміємо його широко, не обмежуючи шкільними процесами навчання та виховання, але й ситуаціями, що мають ознаки педагогічності (виховні дії в сім’ї, повчання старших товаришів тощо).

Прислів'я та приказки є окрасою мовлення, роблячи його насиченим, яскравим, багатим. Саме тому мовлення педагога повинно містити такі одиниці, аби краще пропагувати загальнолюдські цінності, які рпрезентують паремії. Доцільним, як видається, є вживання педагогічних паремій — пласту, що безпосередньо чи опосередковано характеризує навчально-виховний процес чи його учасників, оскільки він імплікує вказівки, що можуть слугувати дороговказом для учня / вихованця в його щоденному шкільному житті.

Навчально-виховний процес має на меті виховання особистості — члена суспільства, здатного пропагувати не лише загальнолюдські, але і його (суспільства) цінності та ідеали. У той же час зміст концептосфер „Навчання” та „Виховання” позначений специфікою сприйняття довкілля різними етносами, що яскраво ілюструє досліджуваний паремійний матеріал, зокрема української, російської та німецької мов. У зв'язку із сказаним лінгвокультурологічний аналіз фразеологічних одиниць і зокрема паремійного матеріалу часто відбувається з опорою на коди, з якими співвідноситься денотативний аспект значення, асоціативно-образні підстави, пов'язані з символами та стереотипами національної культури ${ }^{12}$. Вони дають змогу виокремити базові коди етнічної культури, окреслити іiі домінантні ознаки.

Паремії, що вживаються у сфері педагогічної комунікації, всебічно відображають педагогічну дійсність. Релевантними для досліджуваного паремійного матеріалу є коди, що співвідносяться з такими архетипними уявленнями: предметний (реалізується пареміями, в складі яких є лексеми школа, книга, різка, азбука тощо), біоморфний (реалізуються лексеми курка, яйе, курча, корова, теля та ін.) та інші, що отримують в українській, російській і німецькій мовах специфічну презентацію, зумовлену особливостями мислення народів — їхніх носіїв.

Досліджуваний паремійний матеріал, безперечно, фіксує розходження уявлення про педагогічну дійсність в окреслених лінгвокультурах. Це передусім уявлення про навчальний, виховний процеси, школу, вчителя, вихователя, учня, вихованця тощо.

Поняття школа виражено в педагогічних пареміях усіх трьох досліджуваних мов у звичному значенні — ,заклад, у якому можна отримати освіту”. До цього значення в досліджуваних мовах додається ще одне, що базується на одній із найбільш характерних ознаках школи, - демократична установа, порівн. приклади з української мови: Школа всяким странним дім єсть вольний ${ }^{13}$; Школа дом вольний, а не своявольний ${ }^{14}$. У цьому сенсі наведені паремії перегукуються з німецьким прислів' ям Die Schule soll ein Ziehhaus, aber kein Zuchthaus sein ${ }^{15}$. У кожній із досліджуваних мов на основне значення накладається ще низка специфічних значень, наприклад, в українській мові, з одного боку, простежуємо

\footnotetext{
${ }^{12}$ В. А. Маслова, Лингвокультурология, Москва 2001.

${ }^{13}$ Украӥнські приказки, прислів'я і таке інше, уклав М. Номис, Київ 1993, с. 287.

${ }^{14}$ Там само.

${ }^{15}$ О. Ф. Кудіна, О. П. Пророченко, Зазнач. праия, с. 74.
} 
сакралізацію аналізованого поняття, що виражає, звичайно, позитивну оцінку, наприклад: Школа - церковний угол"1, $з$ іншого, - з'являється й негативна характеристика, наприклад: В нашій школі, як на татарськім полі: $\epsilon c m ь$ где сісmu, та нічого їсти ${ }^{17}$; Школа гола: $є$ де сісти, та нема щзо їсти ${ }^{18}$. У російській мові акцентується увага також на тому, що школа - не єдиний заклад, де навчають, наприклад: Не школа, а жизнь учит ${ }^{19}$. Отже, найбільший спектр значень розкриває паремійний матеріал української мови на позначення концепту школа, причому від позитивної до негативної іiі репрезентації.

У трьох досліджуваних лінгвокультурах мають місце прислів'я-характеристики навчального процесу, які об'єднує одна ідея: навчатися слід протягом усього життя, порівн. нім.: Man wird alt wie eine Kuh und lernt immer noch dazu ${ }^{20}$; Man lernt nie aus ${ }^{21}$; рос.: До смерти учись, до гроба справляйся ${ }^{22}$; Не учись до старости, а учись до смерти ${ }^{23}$, наприклад, укр.: До смерті учиться чоловік ${ }^{24}$; Доки не намучиться, доти не научиться ${ }^{25}$. Проте в українській мові виявляємо прислів'я протилежного змісту, не характерні російській і німецькій мовам: Прийде Май, (школярів) не займай, а Юль, хоч плюнь. Як прийде Май, у книжку дуже заглядай (бо екзамени надходять), а як прийде Юнь, то в книжку плюнь ${ }^{26}$.

Паремійний матеріал української, російської та німецької мов демонструє ситуації, в яких ідеться про те, що для ефективності навчання слід інколи карати учня, наприклад, укр.: За невміння деруть реміння ${ }^{27}$; Аз, буки - бери граматику в руки 28 ; Березовим пером виписувати 29 ; Смажено, печено в смолі, не кажи, щзо ся діє в школі ${ }^{30}$; нім.: Rute macht kein Beulen ${ }^{31}$; рос.: Аз да буки

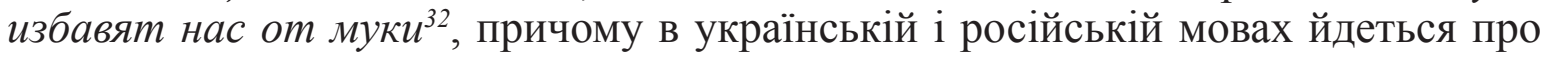
биття як засіб педагогічного впливу, в німецькій - у загальному, без указівки на педагогічну сферу.

Паремії на позначення подібних ситуацій характеризуються структурним і семантичним розмаїттям в українській мові, причому вони не завжди експлікують рекомендацію, а констатують факт, що відбувся. Про це свідчить часова форма дієслів-компонентів відповідних синтаксичних одиниць, наприклад, укр.: Школярської юхи набрався ${ }^{33}$; Аз - били мене раз ${ }^{34}$; Аз - били мене раз,

\footnotetext{
${ }_{16}$ Украӥнські приказки, прислів'я і таке інше, уклав М. Номис, Київ 1993, с. 287.

17 Там само.

18 Там само.

${ }^{19}$ Русские народные загадки, пословицы, поговорки, сост. Ю. Г. Круглов, Москва 1990, с. 311.

${ }^{20}$ Duden. Redewendungen und sprichwörtliche Redensarten. Wörterbuch der deutschen Idiomatik,
} Bearb. von G. Drosdowski und W. Scholze-Stubenrecht, Mannheim; Leipzig; Wien; Zürich, Dudenverlag, 1998, в.11, s. 422.

${ }^{21}$ Там само, с. 517.

22 Русские пословищы и поговорки, под ред. В. П. Аникина, Москва 1988, с. 80.

${ }_{23}$ Русские народные загадки, пословицы, поговорки, сост. Ю. Г. Круглов, Москва 1990, с. 311.

${ }^{24}$ Українські приказки, прислів'я і таке інше, уклав М.Номис, Київ 1993, с. 284.

25 Там само.

26 Там само, с. 287.

27 Там само, с. 285.

28 Там само, с. 286.

29 Там само.

30 Там само, с. 287.

${ }^{31}$ О. Ф. Кудіна, О. П. Пророченко, Зазнач. праця, с. 73.

${ }^{32}$ Русские народные загадки, пословицыл, поговорки, сост. Ю. Г. Круглов, Москва 1990, с. 309.

${ }_{33}$ Українські приказки, прислів'я і таке інше, уклав М. Номис, Київ 1993, с. 287.

34 Там само, с. 286. 
буки - набралися муки; Аз - бив дяк раз; буки - не попадай дякові вдруге в руки ${ }^{35}$. Наявність великої кількості паремій такого плану пояснюється тим, що вони становлять не новий мовний пласт, а відображають реалії, характерні для педагогічної дійсності попередніх століть. Однак в українській і російській мовах виявляємо також прислів'я, що заперечують попередні, як, наприклад, укр.: Наука не йде на бука ${ }^{36}$; рос.: Наука - не бука ${ }^{37}$.

Важливим і складним аспектом у процесі навчання було і $є$ письмо. Вироблення правильного, каліграфічного письма - тривалий і складний процес, тому активно поширені паремії, що оцінюють якість письма, що простежуємо як у російській мові, так і в мові українській, де їх особливо багато, укр.: Пише, як сорока лапою (... сорока по тину) ${ }^{38}$; Написав, мов курка лапою ${ }^{39}$; Се написав, неначе сорока ${ }^{40}$; Написав, як чорт до Арехви ${ }^{41}$; Писав писака, читав собака; Писала писачка, читає собачка; Писав писака: хто прочитає, тому степняка; Як напише писака, то не розбере й собака ${ }^{42}$; рос.: Нацарапал, как курица лапой ${ }^{43}$, а також зміст написаного: Як напише дурень, то не розбере й розумний ${ }^{44}$. У німецькій мові подібні паремії не виявлені. Очевидно, це пов'язане із увагою, яку приділяють каліграфії, гарному письму в українській і російській школах, однак цю якість не виокремлюють у німецьких навчальних закладах як важливу.

Педагогічна комунікація - процес, що відбувається як мінімум між двома його учасниками - учителем і учнем. Найголовніша функція вчителя, як окреслено в дефініції цього поняття в українській, російській і німецькій інтернетенциклопедіях, полягає в передачі знань учням ${ }^{45}$. Прислів'я-характеристики вчителя в досліджуваних мовах відображають цю основну функцію, вказуючи на його найважливішу роль у навчальному процесі, наприклад, укр.: Один учитель краще, ніж дві книги ${ }^{46}$; рос.: От учителя наука ${ }^{47}$; нім.: Ein Lehrer ist besser als zwei Bücher ${ }^{48}$. В українській і російській мовах паремії з компонентом „учитель" репрезентують повагу та шану, простежуємо навіть деяку сакралізація поняття, що засвідчують приклади, укр.: Шануй учителя, як родителя ${ }^{49}$; рос.: Почитай учителя, как родителя ${ }^{50}$. Відповідним прислів'ям німецької мови ці значення не властиві, нім.: Die uns lehren, sollen wir ehren ${ }^{51}$. Очевидно, досліджувані паремії української та російської мов створені в той час, коли статус учителя в суспільстві був високий, а навчання — розкішшю, доступною не всім, хто цього бажав.

35 Там само.

${ }^{36}$ Там само, с. 284.

${ }^{37}$ Русские народныле загадки, пословицы, поговорки, сост. Ю. Г. Круглов, Москва 1990, с. 310.

${ }^{38}$ Українські приказки, прислів'я і таке інше, уклав М. Номис, Київ 1993, с. 286.

${ }^{39}$ Там само.

40 Там само.

41 Там само.

42 Украӥнські приказки, прислів'я і таке інше, уклав М. Номис, Київ 1993, с. 287.

${ }^{43}$ Русские народные загадки, пословицы, поговорки, сост. Ю. Г. Круглов, Москва 1990, с. 311.

44 Украӥнські приказки, прислів'я і таке інше, уклав М. Номис, Київ 1993, с. 286.

${ }^{45}$ Електронний ресурс: ru.wikipedia.org, de.wikipedia.org, uk.wikipedia.org

${ }^{46}$ К. І. Мізін, Німецьько-украӥнський фразеологічний словник (усталені порівняння), Вінниця 2005, с. 215.

${ }^{47}$ Русские народные загадки, пословицы, поговорки, сост. Ю. Г. Круглов, Москва 1990, с. 311.

${ }^{48}$ О. Ф. Кудіна, О. П. Пророченко, Зазнач. праия, с. 90.

49 Українські прислів'я та приказки, упор. та передм. В. Бойка, Київ 1978, 291 с.

${ }^{50}$ Русскиенародные загадки, пословицы, поговорки, сост. Ю.Г. Круглов, Москва 1990, с. 312.

${ }^{51}$ О. Ф. Кудіна, О. П. Пророченко, Зазнач. працяя, с. 76. 
Досліджуваний паремійний матеріал репрезентує батьків як важливих наставників у процесі виховання, зразків для наслідування. Батьківська мудрість має виховуючу силу, є духовним надбанням дітей. Ця думка концептуально закладена в пареміях-характеристиках батьків в українській, російській і німецькій мовах. Різницю вбачаємо в репрезентації батьків як вихователів, наставників. У досліджуваних лінгвокультурах це пов'язано з роллю, що їм відводить те чи те суспільство. В Україні мати й батько мають щонайбільший авторитет, слова батько і мати вимовляються шанобливо: „Батько старший у родині, виконує здавна всі необхідні обряди, пов'язані з родинним вогнищем. Як голова родини, за давнім звичаєм, він господар (пан-господар), порадник у сім'ї, мудрий вихователь своїх дітей" 52 . Це значення акцентується і в українській інтернет-енциклопедії й використовується при інтерпретації поняття батько: “Батько - основа повноцінної сім'ї, має глибокий вплив, особливо у дитинстві, та значення для дитини протягом іiі життя" 53 , у той же час роль матері в житті дитини, як це не дивно, у відповідній статті не кваліфікується ${ }^{54}$.

Досліджуваний паремійний матеріал української мови також відображає важливу виховну роль батька, наприклад, укр.: Ледача та дитина, которої батько не вчив ${ }^{55}$; Діти батька не учать ${ }^{56}$. Поняття батько в українській лінгвокультурі навіть сакралізується, порівн.: Отець - як Бог та Бога - буде тобі всюди дорога ${ }^{58}$.

Українські паремії з компонентом - мати показують іï як годувальницю, люблячу, проте не виявлено паремій, в яких ідеться про матір-виховательку.

Цікаво, що російська інтернет-енциклопедія в дефініціях понять отеи, мать виокремлює лише їхню репродуктивну функцію ${ }^{59}$. Російські прислів'я та приказки з відповідними компонентами чисельні та розмаїті за значенням. Батько в них - авторитетна для дитини людина, його слово важливе, повчальне, наприклад: Отеи сына не на худо учит ${ }^{60}$; Глупому сыну и родной отеи ума не пришьет; Кто не слушает тата, тот послушает ката ${ }^{61}$. Те саме можна сказати й про матір-виховательку: Не научит мамка, так выучит лямка ${ }^{62}$. Не наставит мать - научат добрые люди.

У німецькій Вільній енциклопедії батько й мати постають у трьох статусах: біологічному, соціальному, юридичному ${ }^{63}$, які, однак, не відбиті у відповідному паремійному матеріалі сучасної німецької мови. В німецькій мові прислів'я з компонетами Vater, Mutter у значенні „вихователі” не виявлено. Згадаємо лише одне прислів'я із компонентом „Eltern”: Wer den Eltern nicht folgen will, der muss dem Kalbelle folgen ${ }^{64}$. У німецькій мові ці прислів'я виражають узагальнено наставника: це не лише батьки, наприклад: Erziehst du

${ }^{52}$ В. В. Жайворон ок, Проблема кониептуальної картини світу та мовного ї̈ відображення, [в:] „Культура народов Причерноморья”, 2002, № 32, с. 51-53.

${ }^{53}$ Електронний ресурс: uk.wikipedia.org

${ }^{54}$ Електронний ресурс: uk.wikipedia.org

${ }_{55}^{55}$ Ураїнські приказки, прислів'я і таке інше, уклав М. Номис, Київ 1993, с. 407.

${ }^{56}$ Там само.

${ }^{57}$ Там само, с. 415.

${ }^{58}$ Там само, с. 415.

${ }^{59}$ Електронний pecypc: ru.wikipedia.org

${ }^{60}$ Русские пословищы и поговорки, под ред. В. П. Аникин а, Москва 1988, с. 249.

${ }^{61}$ Там само, с. 151.

${ }^{62}$ Там само, с. 220.

${ }^{63}$ Електронний ресурс: de.wikipedia.org

${ }^{64}$ О. Ф. Кудіна, О. П. Пророченко, Зазнач. праия, с. 217. 
dir 'nen Raben, wird er dir die Augen ausgraben ${ }^{65}$. Подібні прислів'я мають місце і в українській лінгвокультурі, наприклад: Як дуба не нахилиш, так великого сина на доброє не навчищ ${ }^{66}$.

Отже, батьки як суб'єкти виховного процесу найбільш яскраво схарактеризовані в російській лінгвокультурі, де вербалізовані концепти батько й матір як наставники, вихователі. В українській мові найбільш виразно вербалізовано концепт батько, а в німецькій лінгвокультурі паремії з компонентами батько, мати в досліджуваному значенні взагалі не виявлені.

Педагогічна паремія отримує в кожній із досліджуваних лінгвокультур специфічну презентацію базових для педагогічної сфери концептів, зокрема це школа, вчитель, навчальний процес, батько, мати. В українській і російській мовах педагогічні паремії часто відображають неактуальні педагогічні реалії, німецькомовний паремійний матеріал не репрезентує такої особливості.

У слов'янських мовах спостерігаємо сакралізацію понять школа, учитель, батько, що пояснюємо особливістю слов'янської ментальності, в якій духовність $€$ важливим чинником. В українській і російській мовах паремійний матеріал репрезентує батьків як авторитетних людей у процесі виховання. У цьому значенні німецькі іменники Vater, Mutter в пареміях не актуалізовані.

Ситуації, що виникають у сфері педагогічної комунікації, отримують більш повну презентацію в паремійному матеріалі української та російської мов. Вони переважають не лише кількісно, але й позначені різноплановістю репрезентації релевантних для концептосфер „Навчання” та „Виховання” концептів. Проаналізований німецькомовний матеріал цього плану нечисельний, до того ж, досліджувані концепти репрезентовані або однобоко, або не мають місця взагалі.

Подальші наукові розвідки можна спрямувати на дослідження камерної фразеології, що функціонує у сфері педагогічної комунікації, яку репрезентують лінгвокреативні особистості української, російської та німецької лінгвокультур.

${ }^{65}$ Там само, с. 99.

${ }^{66}$ Українські приказки, прислів'я і таке інше, уклав М. Номис, Київ 1993, с. 287. 